\title{
Normal spirometry equates to normal impulse oscillometry in healthy subjects
}

\author{
Brian Lipworth* ${ }^{*}$ and Rory Chan
}

\section{Background}

Impulse oscillometry (IOS) is an effort independent test performed with tidal breathing which can ascertain the presence of small airways dysfunction by measuring the heterogeneity of resistance between 5 and $20 \mathrm{~Hz}$ (R5-R20) or the area under the reactance curve (AX). The article of Li et al. reported on impulse oscillometry (IOS) values in young non smoking symptomatic otherwise healthy subjects with preserved spirometry without a diagnosis of chronic respiratory disease [1]. In subjects who had forced expiratory flow rates $<65 \%$ predicted they reported poor area under curve values $<0.70$ with associated low sensitivity and specificity values on the whole being less than $80 \%$.

In our clinic we would consider pragmatic abnormal IOS values as $\mathrm{R} 5>0.5 \mathrm{kPa} / \mathrm{l} . \mathrm{s}, \mathrm{R} 5-\mathrm{R} 20>0.1 \mathrm{kPa} / \mathrm{l} / \mathrm{s}$ and $\mathrm{AX}>1.0 \mathrm{kPa} / \mathrm{l}$, in terms of being indicative of a clinically relevant degree of airflow obstruction [2]. We would also like to point out that in persistent asthma patients with preserved spirometry who have FEV1 $>80 \%$ predicted, the presence of raised values for R5-R20 was associated with a greater likelihood of long term poor disease control [3]. Moreover small airways dysfunction as R5-R20 and AX is related to type 2 inflammation in asthma [4].

Li et al. have demonstrated that otherwise healthy individuals with symptoms who have abnormal forced expiratory flows also have normal IOS values. Moreover it is important to note that forced expiratory rates are rather volume dependent such that false positive low values are commonly seen when subjects do not exhale fully to

*Correspondence: b.j.lipworth@dundee.ac.uk

Scottish Centre for Respiratory Research, Ninewells Hospital,

Dundee DD19SY, UK residual volume. We would therefore have concerns that clinicians might end up erroneously interpreting what are essentially normal IOS values which would lead to unnecessary further investigation and cause potential unwarranted anxiety to patients with normal tests.

\section{Conclusions}

Impulse oscillometry should be interpreted in the light of abnormal values as being indicative of small airways dysfunction.

\begin{abstract}
Abbreviations
$\mathrm{R} 5$ : Resistance at $5 \mathrm{~Hz}$ (total resistance); R20: Resistance at $20 \mathrm{~Hz}$ (central resistance); R5-R20: Resistance heterogeneity between 5 and $20 \mathrm{~Hz}$ (peripheral resistance); AX: Area under reactance curve; FEV1: Forced expiratory volume in $1 \mathrm{~s}$; IOS: Impulse oscillometry.
\end{abstract}

\section{Acknowledgements}

Not applicable.

\section{Authors' contributions}

$B J L$ and $R C$ were responsible for writing the letter and read and approved the manuscript. All contributors who do not meet the criteria for authorship should be listed in an acknowledgements section. Both authors read and approved the final manuscript.

\section{Funding}

Not applicable.

\section{Availability of data and materials}

Not applicable.

\section{Declarations}

Ethics approval and consent to participate Not applicable.

\section{Consent for publication}

Not applicable.

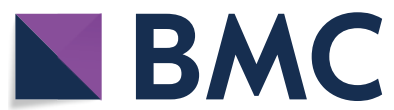

(c) The Author(s) 2021. Open Access This article is licensed under a Creative Commons Attribution 4.0 International License, which permits use, sharing, adaptation, distribution and reproduction in any medium or format, as long as you give appropriate credit to the original author(s) and the source, provide a link to the Creative Commons licence, and indicate if changes were made. The images or other third party material in this article are included in the article's Creative Commons licence, unless indicated otherwise in a credit line to the material. If material is not included in the article's Creative Commons licence and your intended use is not permitted by statutory regulation or exceeds the permitted use, you will need to obtain permission directly from the copyright holder. To view a copy of this licence, visit http://creativecommons.org/licenses/by/4.0/. The Creative Commons Public Domain Dedication waiver (http://creativeco mmons.org/publicdomain/zero/1.0/) applies to the data made available in this article, unless otherwise stated in a credit line to the data. 


\section{Competing interests}

Drs. Lipworth and Chan have no conflicts of interest to report.

Received: 10 March 2021 Accepted: 23 March 2021

Published online: 31 March 2021

\section{References}

1. Li LY, Yan TS, Yang J, Li YQ, Fu LX, Lan L, et al. Impulse oscillometry for detection of small airway dysfunction in subjects with chronic respiratory symptoms and preserved pulmonary function. Respir Res. 2021;22:68.

2. Lipworth B, Manoharan A, Anderson W. Unlocking the quiet zone: the small airway asthma phenotype. Lancet Respir Med. 2014;2:497-506.
3. Manoharan A, Anderson WJ, Lipworth J, Ibrahim I, Lipworth BJ. Small airway dysfunction is associated with poorer asthma control. EurRespir J. 2014;44:1353-5.

4. Kuo CR, Jabbal $S$, Lipworth B. Is small airways dysfunction related to asthma control and type 2 inflammation? Ann Allergy Asthma Immunol. 2018;121:631-2.

\section{Publisher's Note}

Springer Nature remains neutral with regard to jurisdictional claims in published maps and institutional affiliations.
Ready to submit your research? Choose BMC and benefit from:

- fast, convenient online submission

- thorough peer review by experienced researchers in your field

- rapid publication on acceptance

- support for research data, including large and complex data types

- gold Open Access which fosters wider collaboration and increased citations

- maximum visibility for your research: over $100 \mathrm{M}$ website views per year

At BMC, research is always in progress.

Learn more biomedcentral.com/submissions 